\title{
Finding of the Family Bathyclupeidae in the Waters of Vietnam
}

\author{
A. M. Prokofiev \\ Severtsov Institute of Ecology and Evolution, Russian Academy of Sciences, Leninskii pr. 33, Moscow, 119071 Russia \\ e-mail:prokartster@gmail.com \\ Received November 22, 2013
}

DOI: $10.1134 / \mathrm{S} 0032945214030138$

Keywords: Bathyclupeidae, Bathyclupea gracilis, South China Sea, Vietnam

Deepsea herrings in the South China Sea are represented by two species (Bathyclupea gracilis Fowler, 1938, and B. japanotaiwana Prokofiev, 2014), which so far have been found in this area only in the waters of Taiwan. In addition, two more species ( $B$. megaceps Fowler, 1938, and B. nikparini Prokofiev, 2014) can possibly be found in this area, which are known in the adjacent waters of southern Japan and Philippines (Prokofiev, 2014a). For Vietnam and the western part of the South China Sea in general, this family thus far has not been reported (Nguyen et al., 1997).

When examining the collection of deepsea herrings stored in the Zoological Museum of Moscow State University (ZMMU), I found one specimen (ZMMU no. 23444) of standard length (SL) $180 \mathrm{~mm}$ with the following label information: R/V Odyssey, trawl 66, September $25,1984,11^{\circ} 01^{\prime} 0 \mathrm{~N}, 109^{\circ} 55^{\prime} 0 \mathrm{E}$, depth 460-480 $\mathrm{m}$. The main diagnostic characters of this specimen are as follows: oral cavity entirely light, gill cavity dark; pectoral fin light; ventral branch of praeoperculum smooth; 17 developed gill rakers in outer row of first arc and 3+2 tuberculate gill rakers; anal fin rays 30, head length $(l c) 2.9$ times $S L$ (35.0\%); maximum body height $21.7 \% S L$, predorsal and preanal distances 55.6 and $47.2 \% S L$, respectively; longest gill raker length $11.9 \% l c$; pleural ribs on last trunk vertebra well developed. Thus, this specimen completely corresponds to the characteristics of $B$. gracilis and should be attributed to this species. This is the first record of members of this family in the waters of Vietnam.

Therefore, B. gracilis inhabits the entire water area of the South China Sea rather than only its northern part. This species is the most common and widespread member of this family in the western Pacific Ocean, where it is known from Taiwan through Vietnam, Philippines, and eastern Indonesia to the Coral Sea, where it has already been reported for Australian waters (Tzioumis and Keable, 2007). Furthermore, the examined collection includes a specimen (ZMMU no. 17058) caught in the Coral Sea, without precise data on the catch location. On the basis of analysis of count data and photos kindly provided to me by H.-C. Ho (Academia Sinica, Taiwan), it can be assumed that the Deepsea herrings caught by French research expeditions in the waters of New Caledonia and Vanuatu also belong to this species. In the Indian Ocean, this species is apparently absent, and in the subtropical waters of the Southern Hemisphere, including the southwestern Pacific (Tasman Sea), it is replaced by a related species B. elongata Trunov, 1975 (Prokofiev, 2014b).

\section{REFERENCES}

Nguyen, H.P., Nguyen, N.T., Nguyen, P.D., and Do, T.N.N., Checklist of Marine Fishes in Vietnam, Hanoi: Sci. Tech. Publ. House, 1997, vol. 4.

Prokofiev, A.M., Deepsea herrings (Perciformes: Bathyclupeidae) of the Northwestern Pacific Ocean, J. Ichthyol., 2014a, vol. 54, no. 2, pp. 137-145.

Prokofiev, A.M., Fauna of deepsea herrings (Perciformes: Bathyclupeidae) of the Indian Ocean, J. Ichthyol., 2014b, vol. 54 , no. 3 , pp. $311-316$.

Tzioumis, V. and Keable, S., Description of Key Species Groups in the East Marine Region, Sydney: Aust. Mus., 2007.

Translated by M. Batrukova 